\title{
EDITORIAL
}

Convidamos todos os leitores da revista Gestão e Regionalidade a navegar pelo conteúdo da edição n. 108. Essa edição, em particular, reafirma o compromisso da G\&R de dar publicidade ao debate de temas organizacionais, no âmbito da Administração, Contábeis e Turismo, delimitados nas regiões que unem o país em um quase continente, permeado pela diversidade cultural e econômica.

Assim, a edição 108 congrega dez artigos que debatem temas de interesse das organizações públicas e que oferecem importantes reflexões também para a gestão pública. Dois deles discutem aglomerações econômicas: um examina a influência dos clusters localizados em regiões metropolitanas e seu reflexo sobre oferta de trabalho de qualidade e a formação de salários, e o outro investiga os fatores locais que explicam a concentração industrial nos estados brasileiros, considerando o período de 2003 a 2014.

Um dos artigos discute um tema na ordem do dia: o saneamento básico sob a ótica da eficiência e eficácia dos serviços públicos. Outro artigo apresenta o resultado de uma pesquisa sobre presença vigorosa dos três elementos do capital intelectual - humano, relacional e estrutural - no setor do agronegócio e a sua influência na formação dos ativos das organizações contidas no setor. Ainda no setor de agronegócios, outro artigo discute o acesso dos produtores ao crédito rural, utilizando microdados do Censo Agropecuário do IBGE, que levantou informações de mais de 796 mil empresas.

Apresentamos também um artigo que traz um debate sobre o alinhamento entre a estrutura organizacional e o modelo de negócios, a partir de um estudo comparativo entre empresas de grande porte, apontando as mudanças mais significativas ocorridas para viabilizar a implantação do modelo.

Na mesma edição, discute-se um tema instigante e bastante reflexivo: a complexidade econômica de uma região é fator determinante na desigualdade de renda? A pesquisa realizada na região do Grande $A B C$ cobre o período de 10 anos e levanta efeitos heterogêneos da desigualdade de renda. Novamente, a questão econômica é o objeto de estudo no artigo sobre as possíveis relações entre o desenvolvimento financeiro e crescimento econômico, com recorte nas mesorregiões do Rio Grande do Sul.

Ainda, a edição 108 traz um assunto de grande importância no debate sobre sustentabilidade socioambiental, agora com destaque às Instituições de Ensino Superior de capital aberto, no período de 2007 a 2017. A falta de padrão nas informações é um dos destaques do artigo.

A revista finaliza com um artigo que discute a combinação entre elementos da inovação e cultivo sustentável, em um território particularmente instigante, caracterizado pela biodiversidade, e sob a vigilância contínua de todos os países do globo. Neste artigo, destacam-se as práticas de desenvolvimento sustentável dentro de uma reserva indígena.

Ainda, chamamos a atenção para a diversidade metodológica apresentada nesta edição e desejamos a todos boa leitura.

\section{Editoria G\&R}

